\title{
ANALISIS KINERJA MODULASI WAVELET PADA KANAL GAUSSIAN DAN KANAL RAYLEIGH FADING
}

\author{
Lia Astari ${ }^{1}$, Heroe Wijanto ${ }^{2}$, Joko Haryatno ${ }^{3}$ \\ Jurusan Teknik Elektro - Sekolah Tinggi Teknologi Telkom, Bandung \\ [2hrw@stttelkom.ac.id, ${ }^{3}$ jhr@stttelkom.ac.id
}

\begin{abstract}
Abstrak
Sinyal dengan kecepatan bit tinggi akan mengalami kesalahan bit lebih buruk dibandingkan sinyal dengan kecepatan bit rendah. Pada kanal frequency selective fading, kesalahan bit tersebut akan lebih parah lagi. Perbedaan kinerja untuk kecepatan bit yang berbeda ini melahirkan konsep transmisi multirate diversity. Wavelet yang memiliki kemampuan multirate analysis mampu mengimplementasikan strategi multirate diversity melalui modulasi wavelet. Penelitian ini menunjukkan keuntungan penggunaan multirate diversity menggunakan joint estimation strategy, yang menghasilkan perbaikan kinerja sebesar 11,76 dB untuk kanal AWGN. Untuk kanal fading rata dapat dicapai BER $6 \times 10^{-5}$, dan untuk kanal frequency selective fading dihasikan BER $4 \times 10^{-4}$.
\end{abstract}

Kata kunci: modulasi wavelet, Daubechies, Coiflet, Biorthogonal, Rayleigh fading, joint estimation

\section{Abstract}

Signal having fast bit rate has worse error rate than signal with slow bit rate. In frequency selective fading channel the error rate has worse performance. The difference of performances for different rates introduces multirate diversity concept. Wavelet having multirate analysis can implement this multirate diversity strategy by wavelet modulation. The results of this research depict the advantages of multirate transmission diversity, that are using joint estimation strategy results in gain performance equal to 11,76 dB in AWGN channel. The system results BER $6 \times 10^{-5}$ in flat fading channel, and in frequency selective fading channel results BER $4 \times 10^{-4}$.

Keywords: wavelet modulation, Daubechies, Coiflet, Biorthogonal, Rayleigh fading, joint estimation

\section{Pendahuluan}

Salah satu permasalahan yang terjadi pada sistem komunikasi bergerak adalah multipath fading. Sinyal-sinyal yang melalui jalur perambatan berbeda-beda akan mengalami redaman dan delay yang berbeda-beda pula, sehingga menyebabkan interferensi antar simbol (ISI). Akibatnya kesalahan bit di penerima akan meningkat dan kinerja sistem terdegradasi. Probabilitas kesalahan bit tersebut bervariasi untuk nilai rms delay spread ternormalisasi terhadap interval bit yang berbeda [8]. Sedangkan interval bit berbanding terbalik dengan kecepatan pengiriman bit. Perbedaan kinerja untuk kecepatan bit yang berbeda ini melahirkan konsep transmisi multirate diversity.

Transformasi wavelet merupakan teknik pemrosesan sinyal secara multi resolusi yang dapat mengimplementasikan strategi multirate diversity dalam skema modulasi untuk sistem komunikasi bergerak.

Tujuan yang ingin dicapai dalam penelitian ini adalah membandingkan BER modulasi wavelet empat tingkat pada kanal AWGN (Additive White Gaussian Noise) dan flat fading terhadap modulasi BPSK secara teoritis, mengetahui kinerja BER modulasi wavelet di setiap skala/tingkat modulasi jika digunakan kanal-kanal AWGN, Rayleigh flat fading dan frequency selective fading, serta mengetahui pengaruh multirate diversity terhadap perbaikan kinerja modulasi wavelet. Pemodelan, perhitungan dan analisis dilakukan dalam batasan: representasi modulasi merupakan implementasi ekivalen pita-dasar, digunakan empat tingkat filter bank, data (source) dibangkitkan acak dan bernilai biner, jenis fungsi analisis wavelet yang digunakan meliputi Daubechies, Coiflet dan Biorthogonal, proses estimasi dan pengambilan keputusan pada demodulator menggunakan correlator yang sama untuk ketiga jenis wavelet yang berbeda, frekuensi Doppler $60 \mathrm{~Hz}$ dan $120 \mathrm{~Hz}$, rms delay spread bernilai $0,25 \times$ interval bit masing-masing skala.

\section{Transformasi Wavelet dan Kanal Fading}

\subsection{Transformasi Wavelet}

Analisis wavelet merupakan analisis multiresolusi, yakni mampu menganalisis sinyal pada frekuensi berbeda dengan resolusi berbeda. Analisis multi-resolusi wavelet untuk frekuensi tinggi memberikan resolusi waktu yang tinggi dan resolusi frekuensi yang rendah, sebaliknya pada frekuensi rendah memberikan resolusi waktu yang rendah dan resolusi frekuensi yang tinggi [5]. Secara keseluruhan, transformasi wavelet terdiri dari proses-proses untuk mendapatkan set koefisien analisis dan set koefisien sintesis, masing-masing proses dilakukan dengan menggunakan filter bank dan sampling multi-resolusi. 
Filter bank analisis dicontohkan dengan menggunakan dua lengan sebagaimana diperlihatkan di Gambar 1, dengan proses:

$$
\begin{aligned}
& c_{j}(k)=\sum_{m} h(m-2 k) c_{j+1}(m) \\
& d_{j}(k)=\sum_{m} h_{1}(m-2 k) c_{j+1}(m)
\end{aligned}
$$

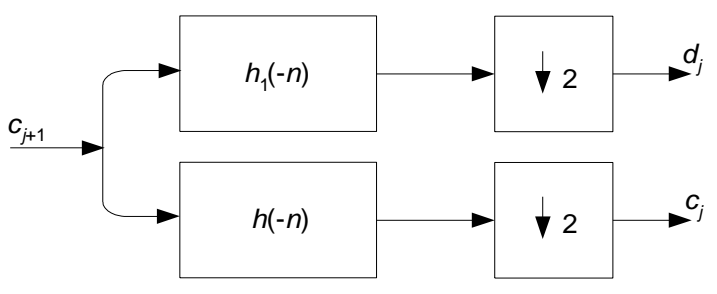

Gambar 1. Filter Bank Analisis Dua Lengan

Koefisien $d_{j}$ dan $c_{j}$ diperoleh melalui proses konvolusi koefisien filter $h(-n)$ dan $h_{1}(-n)$ terhadap koefisien scaling yang lebih tinggi levelnya $\left(c_{j+1}\right)$, kemudian dilakukan proses down sampling terhadap hasil konvolusi tersebut.

Filter bank sintesis dicontohkan dengan menggunakan dua lengan sebagaimana diperlihatkan di Gambar 2, dengan proses:

$$
c_{j+1}(k)=\sum_{m} c_{j}(m) h(k-2 m)+\sum_{m} d_{j}(m) h_{1}(k-2 m)
$$

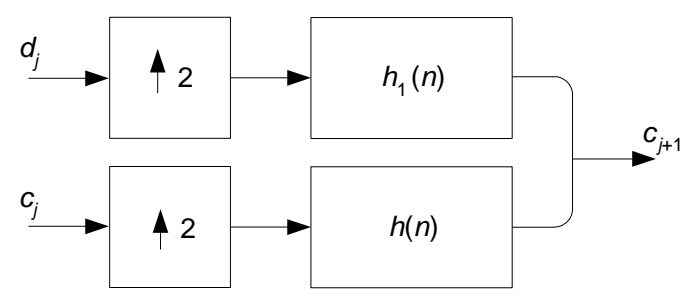

Gambar 2. Filter Bank Sintesis Dua Band

Koefisien $c_{j+1}$ diperoleh melalui proses up sampling (memberi zero padding) terhadap masing-masing koefisien $c_{j}$ dan $d_{j}$, dilakukan konvolusi dengan koefisien filter $h_{1}(n)$ dan $h(n)$ terhadap hasil up sampling tersebut, kemudian hasil konvolusi dari kedua band dijumlahkan.

Terdapat beberapa jenis transformasi wavelet dengan sifat fungsi transformasi yang berbeda, yaitu:

\section{a. Daubechies}

Fungsi Daubechies bersifat compactly supported, orthonormal, dan asimetri [12]. Fungsi Daubechies menggunakan derajat kebebasan yang membutuhkan $N / 2-1$ momen wavelet bernilai nol.

\section{b. Coiflet}

Coifman mengusulkan untuk menetapkan tidak hanya momen wavelet yang bernilai nol, tetapi juga momen scaling function yang dapat memberikan karakteristik lebih simetri. c. Biorthogonal

Perbedaan biorthogonal dengan orthogonal ditunjukkan oleh Persamaan (4):

$$
\sum_{n} h^{\prime}(n) h(n+2 k)=\delta(k)
$$

Pada orthogonal, koefisien $h(n)$ orthogonal terhadap translasi genap $h(n)$ itu sendiri, sedangkan pada biorthogonal, $h{ }^{\prime}(n)$ orthogonal terhadap $h(n)$.

\subsection{Kanal Fading Rayleigh}

Dalam sistem komunikasi bergerak, distribusi Rayleigh sering digunakan untuk menggambarkan sifat statistik selubung kanal multipath yang berkelakuan time varying [8]. Distribusi Rayleigh didapat dari penjumlahan secara kuadratur antara dua Gaussian noise. Probability density function (pdf) distribusi Rayleigh adalah:

$$
p(r)=\frac{r}{\sigma^{2}} \exp \left(-\frac{r^{2}}{2 \sigma^{2}}\right) ; 0 \leq r \leq \infty
$$

dengan $\sigma^{2}$ adalah nilai variansi tegangan selubung sinyal deteksi yang mengalami fading, jika di pengirim dikirimkan sinyal berselubung konstan.

Sinyal-sinyal pada kanal flat fading dapat dimodelkan sebagai:

$$
r(t)=s(t) \operatorname{ray}(t)+n(t)
$$

dengan $r(t)$ adalah sinyal terima, $s(t)$ adalah sinyal yang ditransmisikan, $n(t)$ adalah Gaussian noise dan ray $(t)$ adalah dampak kanal Rayleigh satu lintasan perambatan. Pada kanal flat fading, delay akibat perambatan sinyal juga dapat dianggap flat.

Sinyal-sinyal pada kanal frequency selective fading dapat dimodelkan sebagai superposisi antardua lintasan perambatan sinyal:

$$
r(t)=a_{0} r a y_{0}(t) s\left(t-\tau_{0}\right)+a_{1} r a y_{1}(t) s\left(t-\tau_{1}\right)+n(t)
$$

dengan $\alpha_{0}$ dan $\alpha_{1}$ masing-masing adalah amplitudo ray $_{0}$ utama yang mewakili lintasan langsung dan amplitudo ray $_{1}$ yang mewakili satu lintasan pantul, sedangkan $\tau_{0}$ dan $\tau_{1}$ masing-masing adalah delay pada lintasan perambatan langsung dan pantul.

\section{Model Sistem Modulasi Wavelet}

Perancangan model sistem modulasi wavelet dilakukan secara skematik sesuai dengan diagram blok pada Gambar 3. Di pengirim dibangkitkan aliran data dari suatu sumber data yang selanjutnya diproses oleh modulator wavelet. Setelah dikonversikan menjadi format sinyal analog oleh DAC, selanjutnya keluaran sinyal modulasi wavelet disalurkan melalui kanal transmisi menuju ke penerima. Di penerima, sinyal terima analog dikonversikan menjadi sinyal digital, kemudian dilakukan proses demodulasi wavelet. Setelah hasil demodulasi diestimasi, akhirnya dilakukan regenerasi sinyal data oleh Decision Circuit, sehingga diperoleh recovery data. 


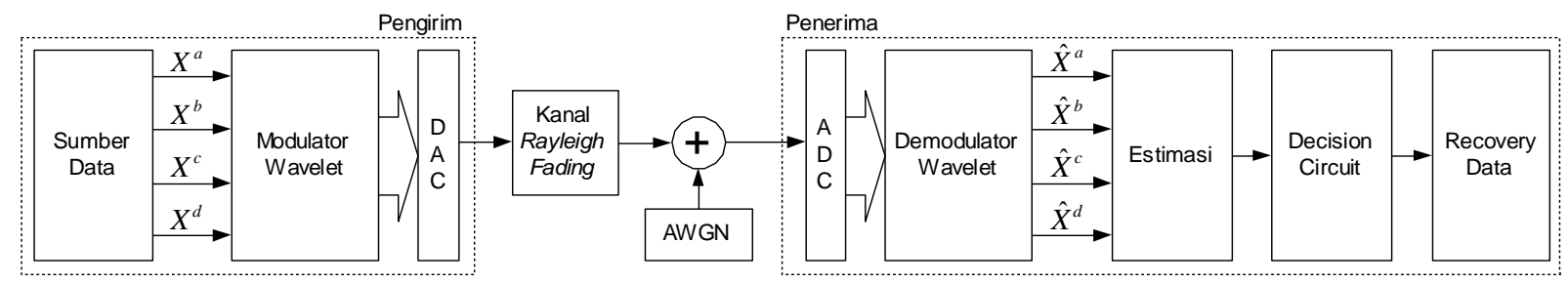

Gambar 3. Sistem Modulasi Wavelet
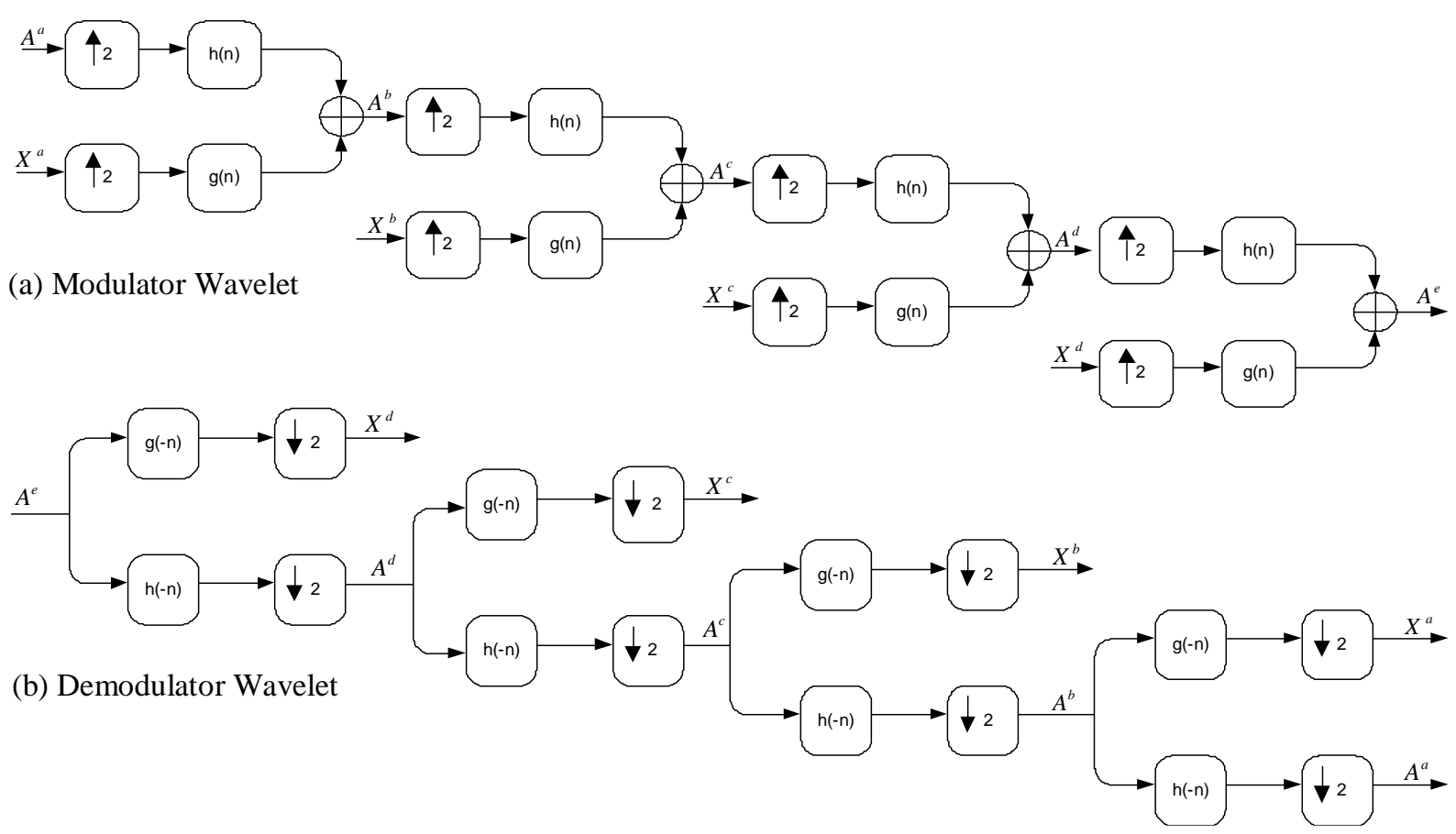

Gambar 4. Modulator dan Demodulator Wavelet

\subsection{Modulator dan Demodulator Wavelet}

Modulator wavelet menggunakan Inverse Discrete Wavelet Transform (IDWT) empat tingkat sebagaimana diperlihatkan di Gambar 4(a). Untuk setiap tingkat IDWT, pada dasarnya dilakukan pemrosesan oleh filter bank analisis dua lengan. Satu lengan dari hasil analisis dilanjutkan lagi dengan proses analisis pada tingkat berikutnya.

Demodulator wavelet menggunakan Discrete Wavelet Transform (DWT) empat tingkat seperti dijelaskan di Gambar 4(b). Untuk setiap tingkat DWT, pada dasarnya dilakukan pemrosesan oleh filter bank sintesis dua lengan. Satu lengan dari hasil sintesis dilanjutkan lagi dengan proses sintesis pada tingkat berikutnya. Jumlah tingkat demodulator disesuaikan dengan jumlah tingkat modulator.

\subsection{Sumber Data}

Bit rate data bernilai $2^{m}$ bps pada setiap lengan keluaran sumber data, dan $m$ merupakan bilangan integer. Pada Gambar 3 terlihat $m \in M$ dengan $M=$ $\{a, b, c, d\}$ beranggotakan bilangan integer berurutan. Nilai ' $a$ ' merupakan coarsest scale dan ' $d$ ' merupakan finest scale. Pemodelan menggunakan jumlah anggota himpunan $M$ sebanyak empat.

\subsection{Estimasi dan Decision Circuit}

Estimasi dapat dilakukan dalam dua metode, yaitu yang pertama hanya dengan menggunakan satu salinan data (single observation) dan yang kedua dengan menggunakan beberapa salinan data pada satu atau lebih skala (joint estimation strategy).

\section{a. Single Observation}

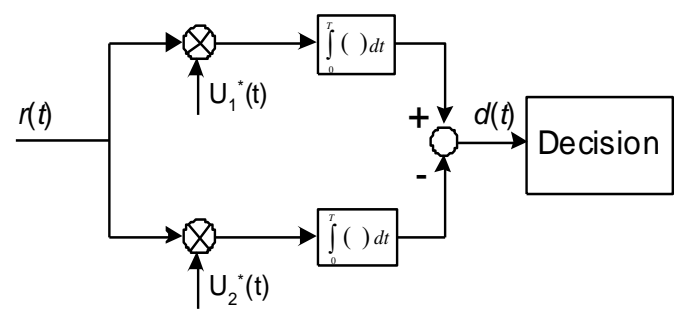

Gambar 5. Single Observation

Estimasi data menggunakan single observation dilakukan melalui correlator dua lengan dan suatu Decision Circuit seperti diperlihatkan pada Gambar 5. Sinyal terima $r(\mathrm{t})$ merupakan sinyal keluaran demodulasi dengan kandungan data kirim yang telah terganggu oleh noise dan fading. Dibuat penetapan nilai-nilai referensi $u_{1}(t)=x_{1}(\mathrm{t})=+1$ dan $u_{2}(t)=x_{2}(t)=1$. Nilai 
threshold pada decision circuit dibuat nol. Hasil decision adalah recovery data $\hat{x}(t)=x_{1}(t)$ jika $d(t)$ bernilai lebih dari nol, sebaliknya $\hat{x}(t)=x_{2}(t)$ jika d(t) bernilai kurang dari nol. Atau dengan kata lain dapat dinyatakan dalam $\mathrm{r}(\mathrm{t})$ :

$$
\widehat{x}(t)=\left\{\begin{array}{l}
+1 ; d(t) \geq 0 \\
-1 ; d(t)<0
\end{array}\right.
$$

\section{b. Joint Estimation Strategy}

Untuk joint estimation strategy dilakukan pengembangan dari single observation dalam beberapa lengan, sebagaimana diperlihatkan pada Gambar 6. Masukan pada masing-masing lengan $\{$ Copy I, Copy II, ..., Copy N\} dicatu oleh masing-masing lengan keluaran dari demodulator wavelet pada Gambar 4(b).

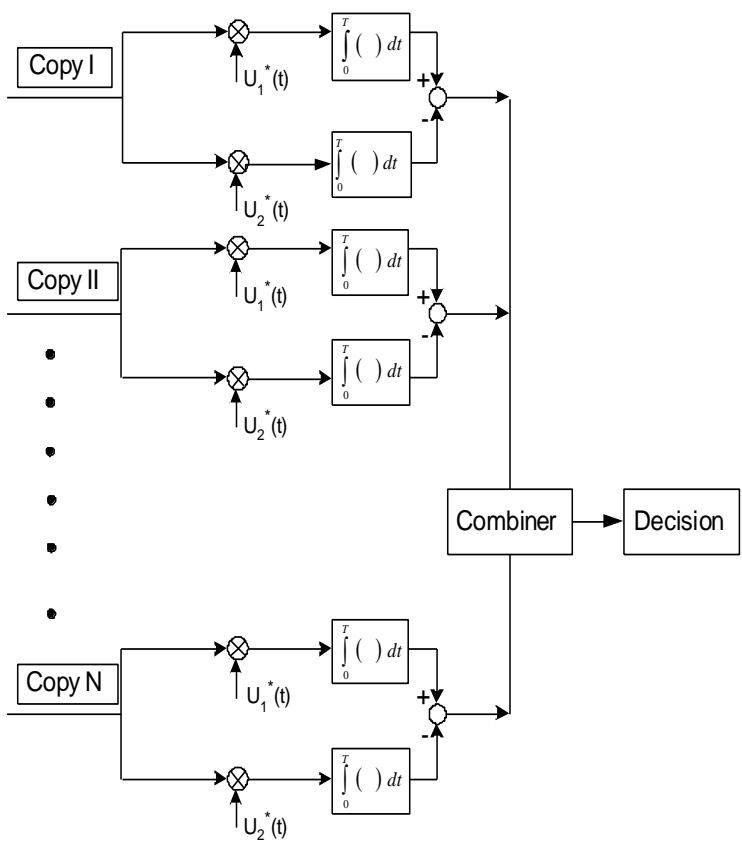

Gambar 6. Joint Estimation Strategy

\subsection{Model Kanal Rayleigh Fading}

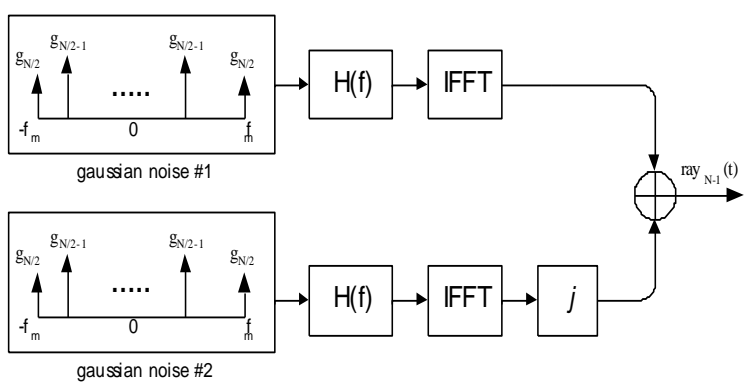

Gambar 7. Model Pembangkit Fading Rayleigh

Kanal fading Rayleigh disimulasikan dalam pemodelan kanal Clarke yang diimplementasikan menggunakan metode simulasi Smith, sebagaimana dijelaskan pada Gambar 7.

\section{Kinerja Sistem Modulasi Wavelet}

Kinerja sistem modulasi wavelet diteliti berdasarkan hasil simulasi yang dilakukan pada model kanal AWGN dan Rayleigh fading (flat fading dan frequency selective fading) dengan sejumlah perubahan kondisi sistem. Skala yang digunakan adalah $m \in M$ dengan $\mathrm{M}=\{14,15,16,17\}$. Dengan demikian, data untuk coarsest scale akan memiliki bit rate $R_{b}=2^{14}$ bps $=16 \mathrm{kbps}$ dan interval bit $T_{b}=61,035 \mu \mathrm{s}$, sedangkan untuk finest scale memiliki bit rate $R_{b}=2^{17}$ bps $=128 \mathrm{kbps}$ dan interval bit $T_{b}=7,63 \mu \mathrm{s}$. Kinerja sistem dinilai berdasarkan BER (bit error rate) yang diamati pada setiap skala dengan menggunakan jenis-jenis wavelet Daubechies, Coiflet, dan Biorthogonal.

\subsection{Kinerja pada Kanal AWGN}

Pada Gambar 8 diperlihatkan kinerja sistem modulasi wavelet Daubechies-3 dari hasil simulasi untuk skala $m=14,15,16,17$ pada kanal AWGN. Pada kanal AWGN, setiap skala memiliki kurva kinerja yang hampir berimpit. Kinerja pada tiap skala, dengan bit rate berbeda, hanya ditentukan oleh kualitas sinyal $E_{b} / N_{0}$ saja, dengan $E_{b}$ adalah energi sinyal dalam satu interval bit dan $N_{0}$ adalah rapat spektral daya AWGN. Kinerja sistem modulasi wavelet Daubechies-3 juga tidak jauh berbeda dibandingkan kinerja sistem modulasi BPSK sebagai referensinya yang memiliki probabilitas kesalahan bit $P_{e}=0,5 \operatorname{erfc}\left[\left(E_{b} / N_{0}\right)^{0,5}\right]$ secara teoritis.

Sistem modulasi wavelet Coiflet-1 dan Biorthogonal-1.3 untuk masing-masing skala pada kanal AWGN juga memiliki kinerja yang hampir sama dengan kinerja sistem modulasi BPSK, seperti terlihat di Gambar 9 dan Gambar 10.

Dengan struktur yang jauh lebih rumit, tetapi dengan kinerja pada kanal AWGN yang tidak lebih baik dibandingkan dengan sistem modulasi BPSK konvensional, maka sistem modulasi wavelet Daubechies-3, Coiflet-1, dan Biorthogonal-1.3 dapat dikatakan tidak layak digunakan.

Hasil-hasil tersebut dapat dipertegas lagi oleh Gambar 11 yang memperlihatkan perbandingan kinerja sistem modulasi wavelet Daubechies-3, Coiflet-1, dan Biorthogonal-1.3 pada kanal AWGN untuk skala sama, yaitu $m=17$, dan dengan menggunakan panjang koefisien yang sama, yaitu 6 . Pada $E_{b} / N_{0}=9,5 \mathrm{~dB}$, kinerja sistem modulasi wavelet Daubechies-3 mencapai BER $=6,92 \times 10^{-6}$, Coiflet-1 mencapai BER $=6,10 \times 10^{-6}$, dan Biorthogonal-1.3 mencapai BER $=8,14 \times 10^{-6}$. Hasilhasil tersebut menunjukkan kesetaraan kinerja sistem modulasi wavelet Daubechies-3, Coiflet-1, dan Biorthogonal-1.3.

Pada Gambar 12 mulai terlihat efektivitas perbaikan kinerja sistem sistem modulasi wavelet Biorthogonal-2.2 dibandingkan dengan kinerja sistem modulasi BPSK pada kanal AWGN. Semakin tinggi nilai skala, semakin baik pula kinerjanya. 


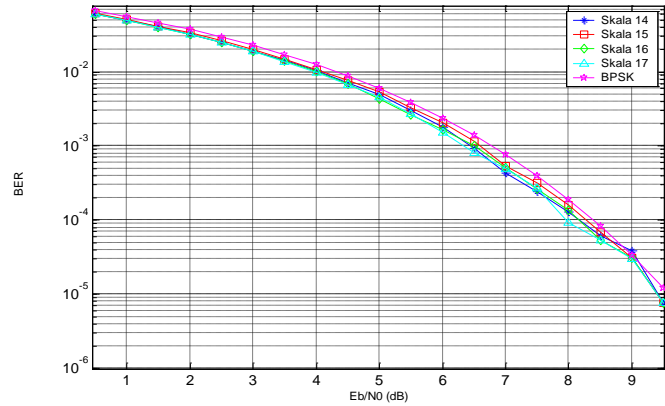

Gambar 8. Kinerja Modulasi Daubechies-3 AWGN

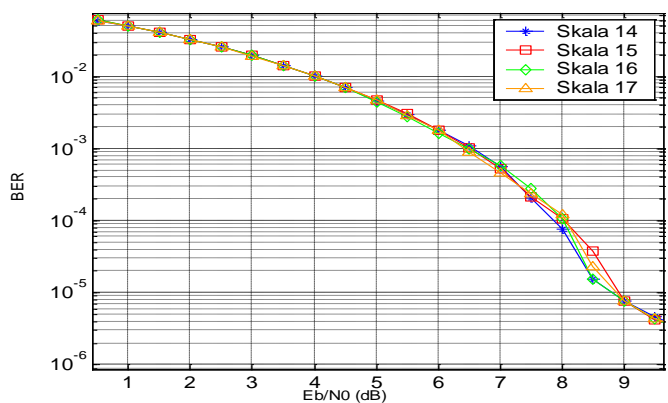

Gambar 9. Kinerja Modulasi Coiflet-1 AWGN

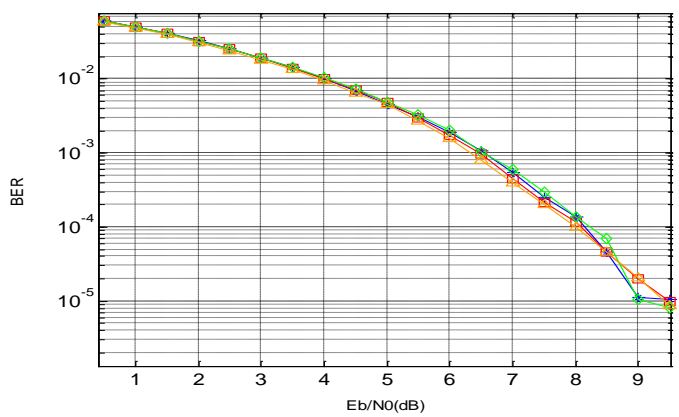

Gambar 10. Modulasi Biorthogonal-1.3 AWGN

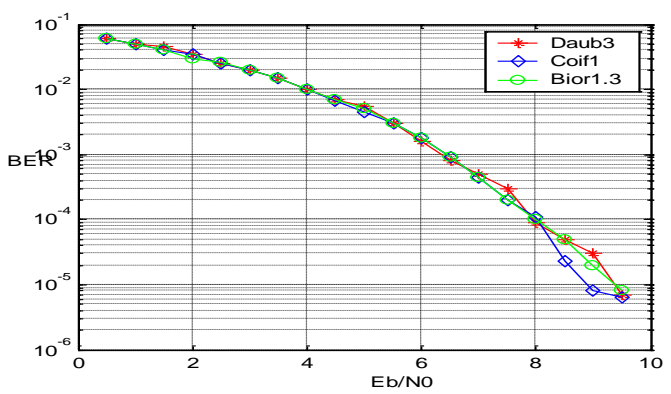

Gambar 11. Perbandingan Kinerja Sistem Modulasi Daubechies-3, Coiflet-1, Biorthogonal-1.3 AWGN

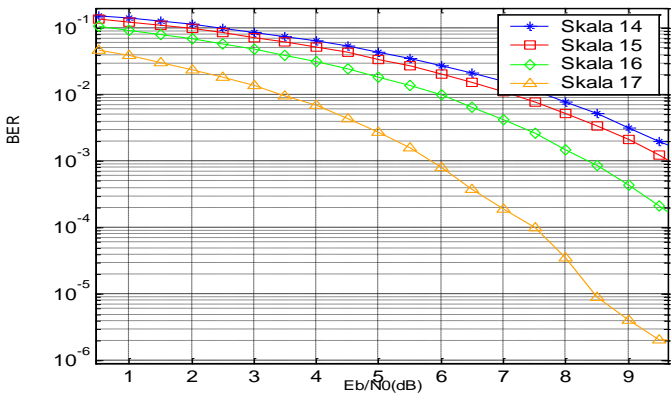

Gambar 12. Modulasi Biorthogonal-2.2 AWGN

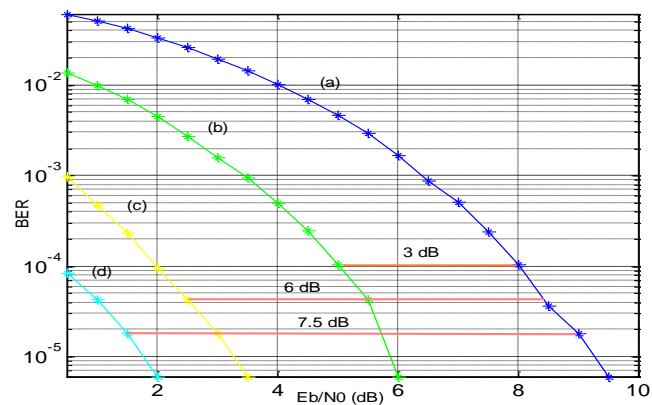

Gambar 13. Modulasi Wavelet Coiflet-2 AWGN dengan Joint Estimation

[(a) $K=1$; (b) $K=2$; (c) $K=4$; (d) $K=6$ ]

Penggunaan joint estimation pada sistem modulasi diharapkan dapat memperbaiki kinerjanya. Strategi joint estimation dapat diimplementasikan pada sistem modulasi wavelet yang memungkinkan pengolahan sinyal secara multi rate, sedemikian hingga secara teoritis memiliki nilai probabilitas kesalahan bit $P_{e}=0,5 \operatorname{erfc}\left[\left(K E_{b} / N_{0}\right)^{0,5}\right]$, dengan $K$ adalah faktor redundancy.

Gambar 13 menunjukkan kinerja sistem modulasi wavelet Coiflet-2 dengan penggunaan joint estimation pada kanal AWGN. Kurva (a) adalah kinerja tanpa redundancy $(K=1)$ pada skala $m=14$. Kurva (b) adalah kinerja hasil gabungan dengan faktor redundancy $K=2$ di skala $m=15$. Kurva (c) adalah kinerja hasil gabungan dengan faktor redundancy $K=4$ pada skala $m=17$. Kurva (d) merupakan kinerja hasil gabungan dengan faktor redundancy $K=6$ pada skala $m=17$ dan $m=16$. Penggabungan dapat dilakukan untuk skala yang sama maupun untuk skala yang berbeda.

Joint estimation menggunakan dua observasi $(K=2)$ memberikan perbaikan kinerja sebesar sekitar $3 \mathrm{~dB}$. Joint estimation menggunakan empat observasi $(K=4)$ memberikan perbaikan kinerja sekitar $6 \mathrm{~dB}$. Joint estimation menggunakan enam observasi $(K=6)$ memberikan perbaikan kinerja sekitar 7,5 dB. Perbaikan kinerja ini sebanding dengan nilai redundancy $K$, atau dengan kata lain diperoleh penguatan kinerja sebesar $10 \log K \mathrm{~dB}$.

\subsection{Kinerja pada Kanal Flat Fading}

Pada Gambar 14 diperlihatkan kinerja sistem modulasi wavelet Daubechies-3 pada kanal flat fading dengan frekuensi Doppler $f_{d}=60 \mathrm{~Hz}$. Kinerja modulasi Daubechies-3 skala $m=14$ tidak jauh berbeda dengan kinerja BPSK dengan probabilitas kesalahan bit $P_{e}=0,5 \times\left[1-\{\bar{\gamma} /(1+\bar{\gamma})\}^{0,5}\right]$ secara teoritis, dengan $\bar{\gamma}$ adalah rataan $E_{b} / N_{0}$ fluktuatif oleh flat fading. Dengan membesarnya skala $m=15,16$, dan 17 diperoleh kinerja yang semakin membaik.

Gambar 15 memperlihatkan kinerja sistem modulasi wavelet Coiflet-1 pada kanal flat fading dengan frekuensi Doppler $f_{d}=60 \mathrm{~Hz}$. Seperti modulasi menggunakan Daubechies, terlihat bahwa 
skala 17 memiliki kinerja terbaik, sedangkan skala 14 memiliki kinerja terendah.

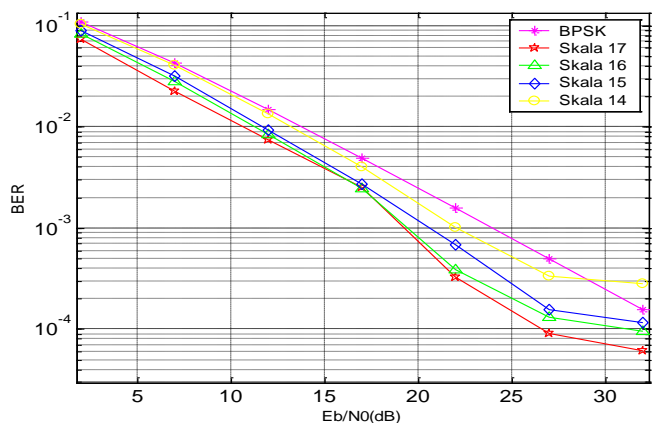

Gambar 14. Daubechies-3 Flat Fading $f_{d}=60 \mathrm{~Hz}$

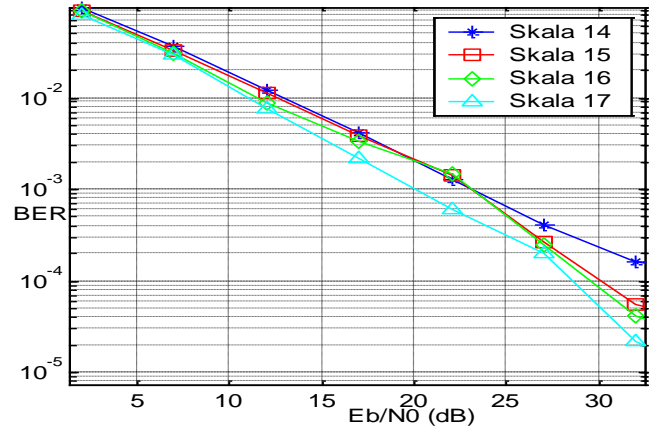

Gambar 15. Coiflet-1 Flat Fading $f_{d}=60 \mathrm{~Hz}$

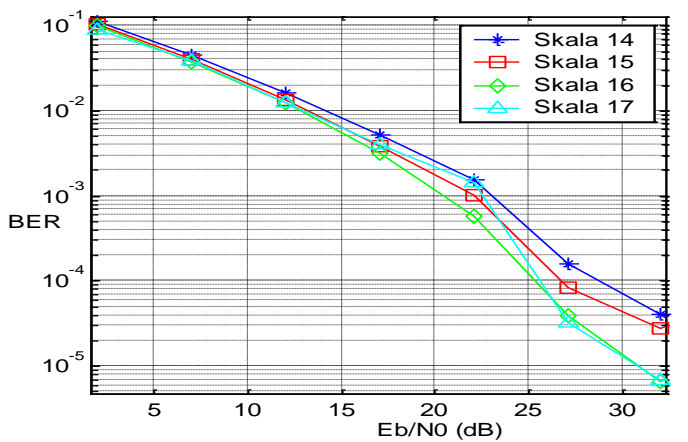

Gambar 16. Biorthogonal-1.3 Flat Fading $f_{d}=60 \mathrm{~Hz}$

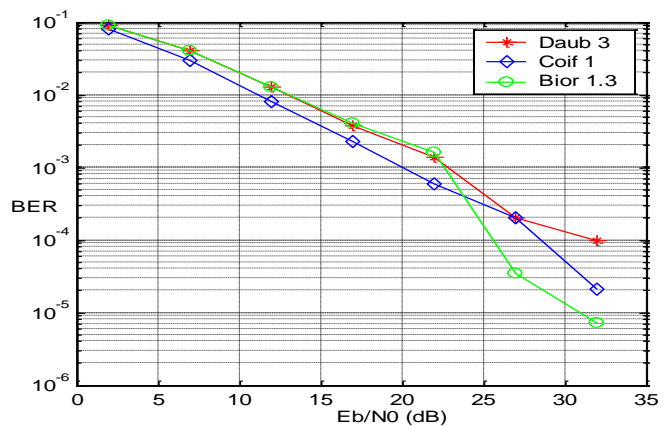

Gambar 17. Perbandingan Flat Fading $f_{d}=60 \mathrm{~Hz}$ Daubechies-3, Coiflet-1, Biorthogonal-1.3

Sistem modulasi wavelet Coiflet-1 dan Biorthogonal-1.3 untuk masing-masing skala kanal flat fading dengan frekuensi Doppler $f_{d}=60 \mathrm{~Hz}$ juga memiliki kecenderungan kinerja yang hampir sama, yaitu semakin membaik untuk skala yang semakin membesar. Seperti yang terlihat di Gambar 15 dan Gambar 16, skala 17 memiliki kinerja terbaik, sedangkan skala 14 memiliki kinerja terendah.

Pada Gambar 17 diperlihatkan perbandingan kinerja sistem modulasi wavelet Daubechies-3, Coiflet-1, dan Biorthogonal-1.3 pada kanal flat fading dengan frekuensi Doppler $f_{d}=60 \mathrm{~Hz}$ untuk skala sama, yaitu $m=17$, dan dengan menggunakan panjang koefisien yang sama, yaitu 6. Pada $E_{b} / N_{0}=$ $32 \mathrm{~dB}$, kinerja sistem modulasi Daubechies-3 mencapai $\mathrm{BER}=5,90 \times 10^{-5}$, Coiflet-1 mencapai $\mathrm{BER}=2,11 \times 10^{-5}$, dan Biorthogonal-1.3 mencapai $\mathrm{BER}=7,3 \times 10^{-6}$. Hasil-hasil tersebut menunjukkan kesetaraan kinerja sistem modulasi wavelet Biorthogonal-1.3 yang memiliki koefisien simetris ternyata lebih baik dari Daubechies-3 dan Coiflet-1.

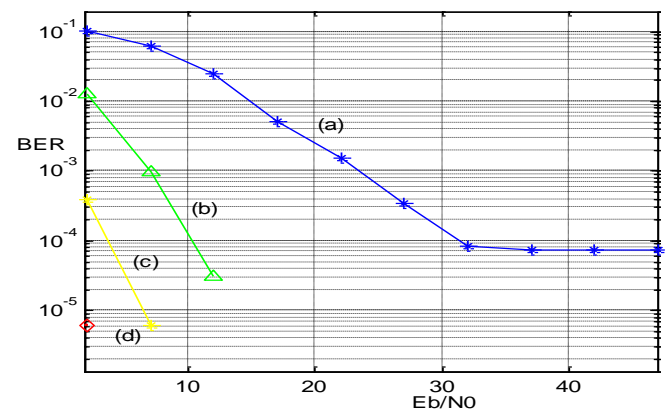

Gambar 18. Modulasi Biorthogonal-1.3 dengan Joint Estimation di Flat Fading $f_{d}=120 \mathrm{~Hz}$ [(a) $K=1$; (b) $K=3$; (c) $K=7$; (d) $K=15$ ]

Gambar 18 menunjukkan perbaikan kinerja joint estimation modulasi wavelet Biorthogonal-1.3 pada kanal flat fading dengan frekuensi doppler 120 Hz. Kurva (a) adalah kinerja tanpa redundancy $(K=$ 1) pada skala $m=14$. Kurva (b) adalah kinerja hasil gabungan dengan faktor redundancy $K=3$ di skala $m=14$ dan 15 , menghasilkan penguatan kinerja sampai $21 \mathrm{~dB}$ (pada BER $=7,20 \times 10^{-5}$ ). Kurva (c) adalah kinerja hasil gabungan dengan faktor redundancy $K=7$ pada skala $m=14,15$, dan 16 , menghasilkan penguatan kinerja sampai $28 \mathrm{~dB}$ (pada BER $=7,20 \times 10^{-5}$ ). Kurva (d) adalah kinerja hasil gabungan dengan faktor redundancy $K=15$, untuk mencapai BER $=6 \times 10^{-6}$ hanya membutuhkan $E_{b} / N_{0}$ $=2 \mathrm{~dB}$. Berarti tidak seperti pada kanal AWGN, Penguatan Kinerja pada kanal flat fading lebih besar dari $10 \log K \mathrm{~dB}$.

\subsection{Kinerja di Kanal Frequency Selective Fading}

Pada Gambar 19 diperlihatkan kinerja sistem modulasi wavelet Daubechies-3 di kanal frequency selective fading. Terlihat bahwa BER akan meningkat dengan menurunnya skala. Jika kanal memiliki rms delay spread $0,25 T_{s 17}$, maka sinyal secondary ray tertunda selama $\tau=0,5 T_{s 17}$. Akibatnya akan terjadi Inter Symbol Interference (ISI). Skala 17 memiliki interval bit yang lebih pendek dibandingkan dengan interval bit skala 14 
yang delapan kali lebih panjang. Karena itu, skala 17 akan terdistorsi lebih berat oleh ISI dibandingkan skala lain yang memiliki interval bit lebih panjang. Dengan demikian, skala 14 memiliki kinerja terbaik, sedangkan skala 17 memiliki kinerja terendah.

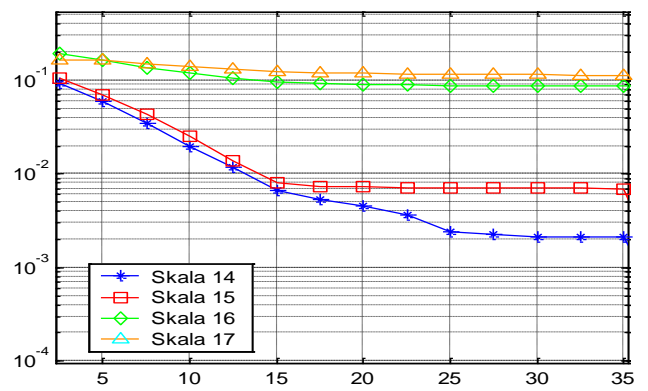

Gambar 19. Kinerja Daubechies-3 $\tau=0,25 T_{s 17}$

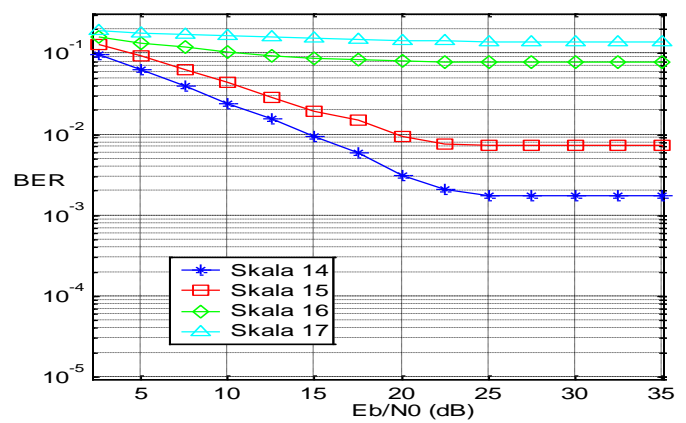

Gambar 20. Kinerja Coiflet-1 $\tau=0,25 T_{s 17}$

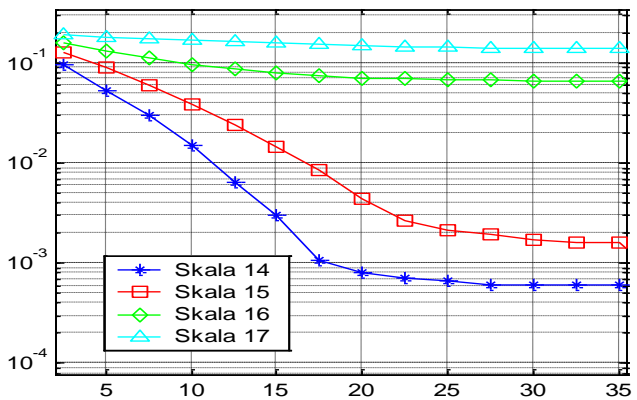

Gambar 21. Kinerja Biorthogonal-1.3 $\tau=0,25 T_{s 17}$

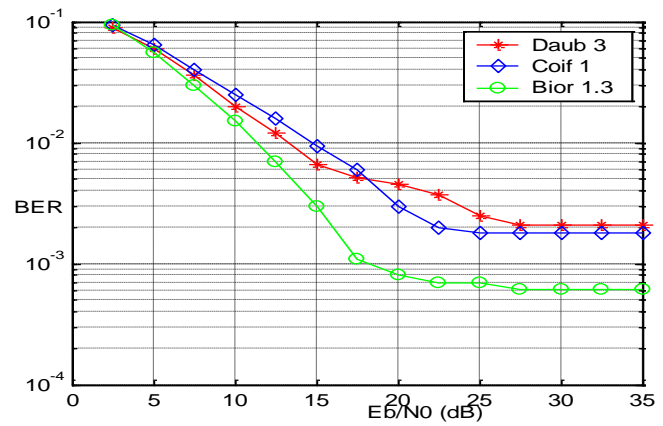

Gambar 22. Perbandingan di $\tau=0,25 T_{s 17}$ Daubechies-3, Coiflet-1, Biorthogonal-1.3 $(m=14)$

Gambar 20 menunjukkan kinerja sistem modulasi Coiflet 1 pada kanal frequency selective fading dengan rms delay spread $\tau=0,25 T_{s 17}$.
Terlihat bahwa masing-masing skala memiliki kinerja yang berbeda, dengan kecenderungan hampir serupa Daubechies-3.

Gambar 21 menunjukkan kinerja kinerja sistem modulasi wavelet Biorthogonal 1.3 pada kanal frequency selective fading dengan dengan rms delay spread $\tau=0,25 T_{s 17}$. Terlihat bahwa masing-masing skala memiliki kinerja yang berbeda, dengan kecenderungan yang hampir serupa Daubechies-3 dan Coiflet-1, namun dicapai kinerja lebih baik.

Gambar 22 menunjukkan perbandingan kinerja sistem modulasi Daubechies-3, Coiflet-1, dan Biorthogonal-1.3 dengan skala 14 pada kanal frequency selective fading dengan dengan rms delay spread $\tau=0,25 T_{s 17}$. Pada nilai $E_{b} / N_{0}=27 \mathrm{~dB}$, tercapai $\mathrm{BER}=2,11 \times 10^{-3}$ dengan Daubechies-3, $\mathrm{BER}=1,80 \times 10^{-3}$ dengan Coiflet-1, dan BER = $6,2 \times 10^{-4}$ dengan Biorthogonal-1.3. Terlihat pula bahwa Biorthogonal-1.3 memiliki kinerja terbaik.

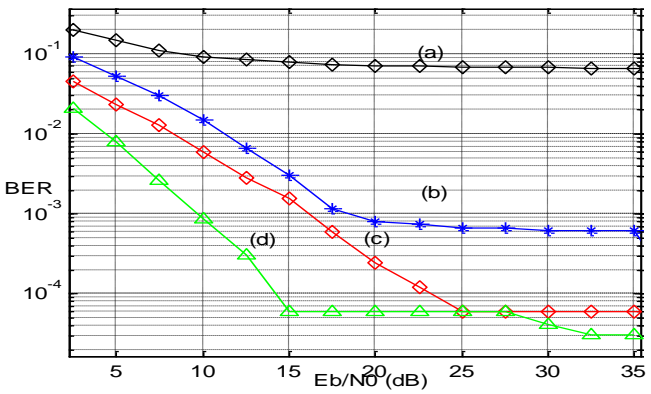

Gambar 23. Modulasi Biorthogonal-1.3 dengan Joint Estimation pada $\tau=0,25 T_{s 17}$

Gambar 23 menunjukkan perbaikan kinerja dari penggunaan joint estimation dalam sistem modulasi wavelet Biorthogonal-1.3 pada kanal frequency selective fading dengan rms delay spread $\tau=0,25 T_{s 17}$. Kurva (a) menunjukkan kinerja BPSK sebagai referensi. Kurva (b) menunjukkan kinerja jika digunakan single observation $K=1$ (skala 14). Gambar (c) kinerja jika digunakan $K=2$ (skala 14 dan 15), menghasilkan Penguatan Kinerja $11 \mathrm{~dB}$ pada BER $=4 \times 10^{-4}$. Gambar (d) kinerja jika digunakan $K=3$ (skala 14 dan 15), menghasilkan Penguatan Kinerja $17,5 \mathrm{~dB}$ pada BER $=4 \times 10^{-4}$.

\section{Kesimpulan dan Saran}

\section{$5.1 \mathrm{~K}$ e s i m p u l a n}

1. Pada kanal AWGN, jika dibandingkan dengan modulasi BPSK, maka kinerja modulasi wavelet empat tingkat jenis orthogonal (Daubechies dan Coiflet) setara di setiap skalanya. Pengggunaan jenis wavelet biorthogonal lebih baik dari BPSK. Sementara pada kanal flat fading kinerja lebih baik, dengan rata-rata Penguatan Kinerja pada Daubechies sebesar $8 \mathrm{~dB}$, Coiflet sebesar $6 \mathrm{~dB}$ dan Biorthogonal bervariasi.

2. Pada kanal AWGN, jika digunakan Daubechies dan Coiflet, modulasi wavelet memiliki kinerja 
yang hampir sama di setiap skalanya. Penggunaan wavelet Biorthogonal menyebabkan kinerja meningkat dengan bertambahnya skala.

3. Pada kanal flat fading, modulasi wavelet pada skala 17 memiliki kinerja terbaik, sedangkan skala 14 memiliki kinerja terendah. Untuk skala 17, Daubechies-3 mencapai rata-rata Penguatan Kinerja sebesar $8 \mathrm{~dB}$, Coiflet- 1 sebesar $6 \mathrm{~dB}$ dan Biorthogonal-1.3 sebesar $12 \mathrm{~dB}$.

4. Pada kanal frequency selective fading dengan rms delay spread $\tau=0,25 \mathrm{~T}_{\mathrm{sn}}$, kinerja terburuk adalah skala $n$, dan skala lebih besar dari $n-2$ tidak dapat digunakan.

5. Pada kanal flat fading, modulasi wavelet Biorthogonal-1.3 $\left(E_{b} / N_{0}=32 \mathrm{~dB}\right)$ memberikan kinerja lebih baik $\left(\mathrm{BER}=5,90 \times 10^{-6}\right)$ daripada Coiflet-1 $\left(\right.$ BER $\left.=2,11 \times 10^{-5}\right)$ dan Daubechies-3 $\left(\mathrm{BER}=7,3 \times 10^{-5}\right)$. Demikian pula pada frequency selective fading, Biorthogonal-1.3 $\left(E_{b} / N_{0}=35 \mathrm{~dB}\right)$ memiliki kinerja lebih baik $\left(\mathrm{BER}=6,2 \times 10^{-4}\right)$ daripada Coiflet-1 $(\mathrm{BER}=$ $\left.1,8 \times 10^{-3}\right)$ dan Daubechies-3 $\left(\right.$ BER $\left.=2,11 \times 10^{-3}\right)$.

6. Walaupun modulasi wavelet empat tingkat memerlukan bandwidth 16 kali lebih lebar dari BPSK, namun dapat memberikan perbaikan kinerja yang tinggi, terlebih lagi dengan digunakannya joint estimation.

\section{$5.2 \mathrm{~S}$ a r a n}

1. Modulasi wavelet yang digunakan pada penelitian ini hanya menggunakan empat tingkat. Untuk penelitian selanjutnya perlu diteliti kinerja jika digunakan tingkat yang berbeda.

2. Kelemahan modulasi wavelet adalah pada efisiensi bandwidth, oleh sebab itu perlu pengembangan menggunakan modulasi dengan konstelasi pada orde yang lebih tinggi.

3. Perlu diteliti estimasi yang tepat terhadap data hasil demodulator pada modulasi wavelet Biorthogonal.

4. Dapat diteliti penggunaan teknik equalisasi pada receiver yang bertujuan skala tinggi yang terdistorsi ISI dapat tetap digunakan.

\section{Daftar Pustaka:}

[1] Burrus, C. S., 1998, Introduction to Wavelet and Wavelet Transform, Prentice Hall Inc.

[2] Fu, S., X. Liu, Wavelet Analysis with Different Wavelet Bases for Engineering Surfaces, The University of North Carolina at Charlotte,. NC 28223.

[3] Manglani, M. J., 2001, Wavelet Modulation in Gaussian and Rayleigh Fading Channel. Blacksburg, Virginia.

[4] Odegard, J. E., Wavelets System with Zero Moments, Rice Univesity, Houston.
[5] Polikar, R., 1996, Wavelet Tutorial, Rowan University.

[6] Proakis, J. G., 1989, Communication System Engineering, Prentice Hall Inc., New Jersey.

[7] Proakis, J. G., 1995, Digital Signal Processing, $3^{\text {rd }}$ Edition. Prentice Hall Inc, New Jersey.

[8] Rappaport, T. S., 1996, Wireless Communication Principles and Practice. . Prentice Hall, New York.

[9] Sklar, B., 1998, Digital Communications Fundamentals and Applications, Prentice Hall Inc., New Jersey.

[10] Sklar, B., Rayleigh Fading Channel in Mobile Communication System, IEEE Communication Magazine, 1997.

[11] Teolis, A., 1998, Computational Signal Processing with Wavelets, Birkhauser.

[12] Walker, J. S., Fourier Transform and Wavelet Transform, Notices of AMS, Vol. 44, 1997. 